\title{
Chapter 10 \\ Diaspora Policies, Consular Services and Social Protection for Finnish Citizens Abroad
}

\author{
Maili Malin
}

\subsection{Introduction}

This chapter provides an overview of Finland's diaspora policies in 2018, mainly focusing on the main features and development of policies in the area of social protection. Finland does not have a specific global policy of supporting Finns abroad, but rather a regional one meaning that Finns living in Nordic countries (Denmark, Iceland, Norway and Sweden) have broadly the same rights than nationals in those countries. The same is true when Nordic nationals live in Finland. This is due to the Nordic joint history, a similar culture and societal system, and Nordic languages (except Finnish). The Nordic model is built largely on a tradition characterised by the strong rule of law, active civil society organisations, equality, solidarity and closeness to nature. Finland has special connection to Sweden, since it was part of Sweden for hundreds of years (1323-1809) and in the 1960s and 1970s, hundreds of thousands Finns moved to Sweden to work (Korkisaari and Söderling 2003; Söderling 2017).

In general, entitlement to the Finnish social protection system is mostly tied to permanent type of residence, which can be seen as an obstacle for Finns abroad in accessing social protection from their homeland. In most cases, Finns are entitled to Finnish social protection when they stay abroad less than 1 year. There are some exceptions, like students, posted workers and civil servants who are covered by the Finnish social security system even if their studies or employment abroad lasts for more than 1 year. ${ }^{1}$ In spite of the Finnish state's limited engagement with

\footnotetext{
${ }^{1}$ Social security institute of Finland Kela. Employment abroad. https://www.kela.fi/web/en/fromfinland-to-another-country-employment-abroad. Accessed 8 March 2019.
}

M. Malin ( $ه)$

Migration Institute of Finland, Turku, Finland

e-mail: maili.malin@utu.fi 
nationals abroad, Finland has developed an advanced form of cooperation in the area of consular and social security cooperation. This de facto benefits a large share of the Finnish population residing abroad, since Finns and Finnish-origin people concentrate in those countries such as Sweden, Canada, Australia, the United States of America (USA) and, more recently, Southern European countries where Finnish retirees increasingly reside. Next to state policies and programmes, non-state institutions are also active in the area of diaspora's access to social protection.

\subsection{Diaspora Characteristics and Home Country Engagement}

\subsubsection{The Finnish Diaspora and Its Relations with the Homeland}

Estimating how many Finnish nationals live abroad is a difficult task. Upon departure, Finns are expected to report to the Local Register Office if they move to another country, but there is no sanction if they fail to do so. ${ }^{2}$ In 2018 , the population of Finnish nationals residing abroad was estimated at around 300,000. ${ }^{3}$ In Germany, there are about 14,000 Finns, 12,000 in Spain and approximately 10,000 in the UK in 2010 (Söderling 2017). Furthermore, it is estimated that 1.6 million individuals of Finnish origin live in 29 countries including people up to third generations. ${ }^{4}$ Most Finnish-origin people live in Sweden (700,000), following important waves of recruitment of foreign workers in Swedish industries during the 1960s and 1970s. In the USA, the Finnish-origin population is estimated to be around one million (Korkiasaari and Söderling 2003; Söderling 2017) and is related to important transatlantic movements in the nineteenth century. According to migration statistics, about 10,000 Finns moved abroad each year with the intention to stay there permanently. ${ }^{5}$

\footnotetext{
${ }^{2}$ Act of Home Municipality (1994). Kotikuntalaki 1994 http://www.finlex.fi/fi/laki/ajantasa/1994/19940201. Accessed 3 March 2019.

${ }^{3}$ Ministry of Interior (2018). Töihin Suomeen - Hallituksen maahanmuuttopoliittinen ohjelma työperusteisen maahanmuuton vahvistamiseksi . Helsinki: Sisäministeriön julkaisuja numero1.

${ }^{4}$ Ulkosuomalaisparlamentti (2017). Hallituksen ulkosuomalaispoliittinen ohjelma vuosiksi 2017-2021.

${ }^{5}$ Official Statistics of Finland (2016). Migration [e-publication]. Helsinki: Statistics Finland. http://www.stat.fi/til/muutl/2016/muutl_2016_2017-05-17_tie_001_en.html. Accessed 6 March 2019.
} 


\subsubsection{Diaspora Infrastructure}

The main Finnish actor that delivers services to citizens abroad are Finnish missions and consulates. The Ministry of Foreign Affairs of Finland is the highest responsible authority governing these missions and their services abroad. Finnish missions assist Finnish citizens and foreigners permanently living in Finland with issues concerning consular services according to the Consular Act (1999). Part of consular services relies on multilateral and bilateral treaties beside obligations under the European Union (EU) law and national legislation. ${ }^{6}$

Consular missions refer to consulates general, consulates, and offices under the administration of a consulate general headed by a career official, or honorary consulates led by an honorary consul. The Consular Services Act 498/19997 (amendments up to $896 / 2015$ included) lays down the provisions on the consular functions for the purpose of providing assistance to Finnish citizens or entities or overseeing their interests and rights. ${ }^{8}$

Consular services are given by 90 mission offices in 75 countries. The Finnish embassies and consulates general are located around the world promoting the interests of Finland and Finns abroad in many ways. In addition, Finland has about 400 honorary consulates, who are private individuals taking care of honorary consular tasks on a part-time basis without remuneration. On a specific geographical area, an honorary consul monitors the rights of Finns and foreigners permanently residing in Finland. Together with diplomatic missions, the honorary consul promotes economic and cultural relations between Finland and the country in question. The honorary consul can advise Finnish companies in obtaining information about local business culture and in finding cooperation partners. In distress situation, the honorary consul advices and gives needed guidance for Finnish citizens who are temporarily abroad. He/she may also assist Finns in their contacts with local authorities or the nearest Finnish embassy or consulate. Limited types of notarized certificates can be acquired through an honorary consul. Honorary consuls do not accept passport applications nor do they handle matters pertaining to visas or residence permits and they cannot serve as attorneys in judicial proceedings or as legal advisers (Consular Service Act 498/1999, 10§.)

A key feature of Finland's diaspora infrastructure is the reliance on the Nordic cooperation that allows its citizens abroad to benefit from a favorable treatment from consular and social protection authorities of other states. Indeed, the specificity of Finland is the existence of several agreements with other Nordic countries Finland, Denmark, Iceland, Norway and Sweden - which allow Nordic citizens and

\footnotetext{
${ }^{6}$ Consular and Diplomatic Protection (2010). Legal framework in the EU member states. Firenze, EU Commission, CARE project Citizens Consular Assistance Regulation in Europe.

${ }^{7}$ Consular Service Act 498/1999. https://www.finlex.fi/fi/laki/ajantasa/1999/19990498. Accessed 5 March 2019.

${ }^{8}$ Ministry of Foreign Affairs, Finnish Missions abroad. https://um.fi/missions. Accessed. 10 March 2019.
} 
permanent residents abroad to turn to another Nordic country's embassy if her/his country does not have a own mission on site (Helsinki Treaty 28/1962 §34). In those circumstances, Nordic embassies are expected to deliver the same services as Finnish embassies, except for the issuance of passports. ${ }^{9}$ Beside this advanced form of consular cooperation, the Nordic cooperation includes a wide range of cooperation in the area of social protection, as discussed below.

The Nordic cooperation began in 1954, when passport control was ended between countries. In 1962, the Treaty of Cooperation (Helsinki Treaty) between the Nordic countries was signed following the language agreement in 1981, a common Nordic labour market in 1982, the agreement on social security in 1981, the Nordic Convention on Social Assistance and Social Services in 1994 and the Agreement on Admission to Higher Education in 1997. Additionally, there are about 60 other joint Nordic agreements. These agreements aim to provide equal access to social and health benefits to all Nordic nationals living in another Nordic country. The main official bodies of the Nordic cooperation are the Nordic Council (NC) founded in 1952, and the Nordic Council of Ministers (NCM) founded in 1971. ${ }^{10}$

In addition to the EU and the Nordic frameworks, Finland has several bilateral social security agreements with other countries that concern employees and their family members. Finland has separate bilateral agreements on social security with Australia, Austria, Canada, Chile, China, Greece, Germany, India, Israel, Latvia, Luxemburg, the United Kingdom, the United States, Spain, South Korea and Switzerland. As discussed below, there are some variations concerning the types of benefits included in the country specific agreements.

Next to consular authorities, several non-state institutions deliver services for Finnish nationals abroad in the Finnish or Swedish language. Many of these institutions have regular funding from ministries for maintaining their activities and, in some instances, perform activities abroad with a mandate of the home country authorities. The oldest non-state organisation is the Finland Society (Suomi-Seura) whose main office is based in Finland. It is an association that has individual and organisational members around the world. Its mission is to be a unique centre of expertise and service for Finns living abroad. The Finland Society conducts lobbying activities and aims to strengthen the connections between Finland and what it considers to be the 1.6 million expatriate population. In other words, its goals are to promote interactions between expatriates and Finns, cultivate cultural contact and strengthen Finland's image abroad. The Finland Society provides services to Finns abroad by giving advice upon moving from Finland, upon returning to Finland, or in administrative matters related to their life aboard. The advice and help is given

\footnotetext{
${ }^{9}$ See footnote 5 .

${ }^{10}$ Ministry of Foreign Affairs. Nordic cooperation. https://um.fi/intergovernmental-nordic-cooperation Accessed 10 March 2019.

Ministry of Social Affairs and Health. Social Security Internationally. https://stm.fi/kansainvalinen-sosiaaliturva?p_p_id=56_INSTANCE_7SjjYV V YeJHp\&p_p_lifecycle=0\&p_p_ state $=$ normal \&p_p_mode $=v i e w \& p \_p \_c o l \_i d=$ column $-2 \& p \_p \_c o l \_c o u n t=2 \& \_56 \_$ INSTANCE_7SjjYYVdYeJHp_languageId=en_US. Accessed 9 March 2019.
} 
via their website, by phone or by email. Services are given by professional salaried persons and by a lawyer when needed. The organization publishes its own magazine and acts as a secretariat for the Finnish Expatriate Parliament (see below).

Among the key activities that are closely linked to the state, the Finland Society provides grants to Finnish expatriate communities and to Finnish media working abroad. These grants for cultural and recreational activities of expatriate Finns are funded by the Ministry of Education and Culture. One additional activity of the Finland Society is the maintenance of Finnish schools for expatriate children and adolescents in their free time by giving grants to local actors for maintaining the schools and by organising updating education for teachers. In Finnish schools, children and youth can learn and maintain their Finnish language skills and learn about Finnish culture. There are about 140 Suomi-schools in 45 countries and over 4300 children and adolescents participate in them each year (Strandberg 2018).

Another important non-state institution is the Finnish expatriate parliament (Ulkosuomalais-parlamentti or FEP, established in 1997) which is funded and operated by the Finland Society. ${ }^{11}$ As many as 531 Finnish expatriate organizations in 39 countries have ratified FEP's by-laws. FEP promotes the interest of all expatriate Finns, being their direct link to the Finland Society. Though it is not a public body, it acts as a consultative body providing opinions to foreign authorities in matters of interest for Finns abroad. The politically non-aligned FEP is a cooperative forum, where Finns living around the world collectively decide on issues they deem important. FEP's main target groups are the Finnish Government and Parliament. FEP is a medium through which the collective decisions of Finnish expatriates are transmitted to the Finnish Government and non-governmental organisations. Moreover, FEP is a lobbying organ which ensures that the views of expatriates receive adequate attention in Finnish public policy decision-making. Its activities are based on the initiatives or motions for resolutions made by the Finnish expatriate organisations, and on the subsequent resolutions adopted by their representatives at the parliament assembly session in Helsinki. ${ }^{12}$

These non-state actors play a key role in the design of Finland's policies towards its diaspora. Every 5 years, the Ministry of the Interior coordinates the preparation of the Policy Program for Finns Expatriate (Ulkosuomalaisparlamentti 2017) with other ministries, the Finland Society and the Finnish Expatriate Parliament. The thematic policy issues in the program for the period 2017-2021 are: the maintenance of Finnish identity among Finnish descents; the improvement of the legal status of expatriate Finns in Finland; improvements of expatriates' social security and health care; taking into account the knowhow of expatriates for Finnish business life; supporting the return of expatriates and; supporting the academic studies concerning Finnish immigration and expatriates.

\footnotetext{
${ }^{11}$ Finnish Expatriate Parliament. Ulkosuomalaisparlamentti. http://www.usp.fi/index.php?lang=uk $\&$ PHPSESSID=f0121a7701620a8a5defed8f18b1ff77. Ministry of Foreign Affairs. Finnish missions abroad. https://um.fi/missions Accessed 4 March 2019.

${ }^{12}$ Finland Society (Suomi-Seura). https://suomi-seura.fi/. Accessed 5 March 2019.
} 
Other non-state institutions that are relevant for Finns abroad are the Finnish Lutheran Congregations. The Finnish Seamen's Mission is a politically neutral nonprofit association whose historical mission is to provide a worship and meeting place for Finns abroad. Seamen's Missions are located in Greece, Belgium, Germany, the UK and the Netherlands. The missions have a traditional role of responding to the needs of travelers by providing information on the local context and access to equipment such as telephone, e-mail and, in some cases, accommodation. They also perform an important role in the community life of Finnish communities by hosting weddings and funerals, christenings and other baptisms, Sunday school, confirmation school and bible circles, devotions and religious services. Another relevant institution in the community and religious life of Finns abroad are the Evangelical Lutheran Church of Finland that serves Finns in 37 countries. The local Finnish parish usually serves as meeting points for Finnish communities and provide a place to practice religion, socialize, read Finnish papers and books or take part in various social activities. ${ }^{13}$

\subsubsection{Key Engagement Policies}

As the main actor in the implementation of Finnish policies and services to citizens abroad, consulates provide assistance and advice. Beside the traditional passport issues and notarial services, Finns abroad receive services concerning different events of their life course such as birth, marriage, divorce and death. In these cases, the main task of consulates is to forward information to the Finnish Population Information System that is a registry that opens the right to vote to citizens abroad and has implications in terms of access to welfare benefits upon return to Finland. ${ }^{14}$

Consulates assist citizens in distress in cases of sudden illness, accidents or crimes and in any other crisis situation in their host country. Finnish consulates can help victims of crisis so that they can get medical care, immediate assistance, contacts with next of kin, or emergency economic help (see below). In case of a Finn's death, the mission will help when needed with the arrangements related to the burial, cremation or repatriation of the deceased. Burial expenses are repayable by the family members of the deceased person. Lastly, consulates can also provide Finns abroad with a repayable loan in case of distress (see below), whereas honorary consuls only provide assistance by contacting local authorities or the nearest Finnish embassy or consulate general (Act of Consular Services 1999). To confirm the impression that consulates only intervene in a limited way and in exceptional circumstances, the Ministry of Foreign Affairs also identifies on its website a long

\footnotetext{
${ }^{13}$ Evangelical Lutheran Church of Finland Global network. https://evl.fi/. Accessed 6 March 2019.

${ }^{14}$ Government Decree of Population Information System 2010/128. Valtioneuvoston asetus väestötietojärjestelmästä 2010/128 https://www.finlex.fi/fi/laki/ajantasa/2010/20100128. Accessed 15 March 2019.
} 
list of activities that Finnish embassies and consulates cannot conduct such as paying hotel and hospital bills or intervening in a legal process.

Outside of basic consular services, a key engagement policy concerns the right to vote of Finnish citizens who are at least 18 years old. The Finnish missions organize advance voting for national parliamentary and presidential elections, as well as for European Parliament elections held in Finland, so that those Finns abroad entitled to vote may exercise this right in Finnish elections. The Population Information System has information about the address of Finns aboard, and it sends them a letter of advice to vote in the nearest Finnish consulate. For the 2015 parliamentary elections, the invitation to vote was sent to 170,000 nationals in 187 countries (Helin 2017). In 2018, Finns abroad obtained the right to vote by mail that was implemented for the first time in the parliamentary elections of April 2019 (Castren 2018). Finnish citizens who are either temporarily or permanently abroad have a right to vote in all national elections and can stand as candidate in national elections.

In terms of economic policy, Finland has double taxation agreements ${ }^{15}$ with a large number of countries (including all Member States of the Organisation for Economic Cooperation and Development- OECD), but there are no housing or remittance policy targeting Finnish nationals abroad. On the contrary, cultural and educational programs abroad are numerous, but some — as noted above — are run by the not-for-profit sector that receives funding from the Government to operate. For instance, there are 17 Finnish independent non-profit cultural and academic institutes around the world maintained by a private foundation or fund (in Japan, Denmark, Germany, Sweden, the UK, Norway, Hungary, Greece, Italy, the Middle East, Estonia, Russia, the USA, France, Benelux, Spain). These institutes promote cooperation between Finnish and international cultural and academic organizations and professionals. They are expert organisations supporting Finnish arts, culture and research around the world and thus, they advance Finnish professionals international mobility, visibility and collaboration. Furthermore, they organise exhibitions, seminars, courses and other events, and run residency and mobility programs for arts professionals and researchers. ${ }^{16}$

As noted earlier, a key educational policy consists in supporting 140 part-time complementary Suomi-schools where Finnish languages and culture to Finnishorigin children are taught in 45 countries all over the world. Additionally, there are six full-time primary education Suomi-schools with Finnish curriculum in Spain, Belgium, Estonia and Russia (Strandberg 2018).

\footnotetext{
${ }^{15}$ Board of Taxation. Verohallinto. Tax treaties. Verosopimukset. https://www.vero.fi/en/detailedguidance/guidance/49062/tax_treatie/) Accessed 4 March 2019.

${ }^{16}$ Finnish Cultural and Academic Institutes. Suomen kulttuuri- ja tiedeinstuutit. https://instituutit. fi/en/. Accessed 7 March 2019.
} 


\subsection{Diaspora Policies and Social Protection in Finland}

As we will show in this section, Finns abroad who wish to access to the Finnish health and social welfare services see their conditions of access influenced by a series of mechanisms that include their country of residence, the existence of bilateral social security agreements or the existence family ties or property. A key feature of a residence-based social security system like Finland's entails that a person has the right to social security benefits as well as healthcare and social welfare services upon demonstrating that his/her residence in Finland is permanent.

When a Finn moves abroad, he/she needs to notify Kela-the Social Insurance Institution of Finland-about his/her move to another country. As an exception, permanent residents in Finland can live abroad, usually for up to a year, and remain within the scope of the Finnish social security system. Kela determines, governs and delivers family benefits (maternity package, child benefit, partial care allowance) sickness matters (reimbursement for medicine, sickness allowance, travel costs), unemployment-related benefits and services (unemployment benefit, activation model), student's grants, disability pensions and benefits, housing benefits, pension and rehabilitation issues in general. Kela also decides and governs international social and health care matters discussed in this chapter. ${ }^{17}$

Besides informing Kela, citizens who move abroad are expected to also notify the Local Register Office about their move and provide a new address. Maintaining up to date information about their address is therefore critical for Finns abroad to keep their administrative exchanges with Finland and the right to vote from abroad. Still many Finns or residents in Finland do not inform the state authorities about their move abroad and therefore, the Population Information System is not fully reliable when it comes to citizens abroad. While cases of misuse of Finnish social benefits by Finns abroad who are not eligible for these benefits exist, scholars have noted that cases of no-recourse to entitlement by individuals who are eligible are actually much more frequent (Lötjönen 2013; Savolainen 2015; Uhari 2016).

For citizens who return to Finland after residing abroad, the speed at which they regain access to benefits is determined by Kela based on their assessment of the strength of connections of the individual with Finland. The connections are considered close if a person has family members and home (registered home and home municipality, usually private property) in Finland. In making a decision, Kela takes also into consideration individual circumstances like periods of residency abroad and in Finland. However, since access to the Finnish social security system is residence-based, as discussed below, Kela's mission towards citizens abroad consists in informing them about their rights and, most importantly, in determining whether they have the right to receive Finnish social benefits abroad. I will argue that while the EU framework is the prime instrument that regulates access to social protection for Finns abroad, agreements signed between Nordic countries and a limited number of bilateral social security agreements with key destination

${ }^{17}$ Kela https://www.kela.fi/. Accessed 9 March 2019. 
countries such as the United States, Canada, Chile, Israel, Australia form the core of Finland's social protection policies towards citizens abroad.

\subsubsection{Unemployment}

Like all EU citizens, a Finn can go for job hunting in an EU or European Economic Area (EEA) country or Switzerland and maintain her/his unemployment benefits for maximum 3 months. Similarly, Finns who try to find work outside the EU may maintain their Finnish unemployment benefits temporarily (less than 1 year) if they are also registered as active job seekers in Finland at the same time. This means that if they receive a work opportunity in Finland, they should take it as soon as possible and return to Finland. In addition to these provisions on unemployment benefits, Finns who wish to work abroad can ask for compensation for travel and overnight stays of return trips to seeking job in another EU/EEA country if the work lasts at least 2 weeks and the average working time is at least $18 \mathrm{~h}$ a week.

According to the Nordic Convention on Social Security (2014), a 5-year rule applies in determining the unemployment allowance when a person has worked in different Nordic countries and wants to return to his/her home country. This rule means that when a Finn become unemployed in another Nordic country and wants to return to Finland, the employment time in other Nordic country is taken into account when determining the unemployment benefit. However, one precondition is that a Finn or permanent resident in Finland has worked also in Finland or received unemployment allowance from Finland in the previous 5 years before this new unemployment period. Lastly, the role of Finnish consulates is very vaguely defined in this area, but they can give advice and information face to face, by email or by phone in unemployment-related matters to nationals residing abroad.

\subsubsection{Health Care}

Finnish nationals have universal health and social insurance in Finland that is governed by Kela. The private health insurance is the most important issue to purchase when travelling outside EU/EEA countries, despite the many bilateral social security agreements. There is some preferential access to public healthcare in destination countries, for example Finnish pensioners living in Chile are entitled to the same public health care services as locals. ${ }^{18}$

However, Finland's most visible engagement for the health care of citizens abroad is visible at the Nordic regional level. The Nordic cooperation in health

\footnotetext{
${ }^{18}$ Chile social security agreement. https://www.choosehealthcare.fi/health-services-abroad/country-specific-information-about-health-services/chile/. Accessed 10 of March.
} 
matters is particularly advanced with Sweden, Norway, Iceland and Denmark and it concerns only public health care services. It is noteworthy, for instance, that individuals who have the right to social security and health insurance in Finland do not need a European Insurance Card to receive necessary treatment in Nordic countries. Only an ID and a current address in Finland is needed for one to access public health care at the same cost as nationals of that country (Sweden; Nordic Convention on social security 2004.) Similarly, the Convention also provides for the reimbursement of costs for the return journey home from another Nordic country in cases of illness. ${ }^{19}$

Even though these are policies of the destination country, it should be noted that since Sweden hosts one of the largest Finnish community and the Finnish language is one of the official minority languages, different services are offered to this population, which places them in a more privileged position than Finns residing in other destination countries. These services include the right to interpreters in health care, the right to day care and elderly care in Finnish language, the availability of mental health services in Finnish language (psychiatrists and psychologists) in certain areas where there are enough Finnish-speaking people (Korkiasaari and Söderling 2003).

Next to these policies facilitating access to healthcare, there are few Finnish actors involved in the provision of information for accessing healthcare abroad when living overseas. As in many EU Member States, the Ministry of Foreign Affairs provides information on its website on how to prepare oneself for travelling abroad. ${ }^{20}$ Similarly, the National Institute for Health and Welfare (THL) maintains web pages where health advices are given and where required vaccination by each country is listed. In particular, the Choosehealthcare.com website run by the Ministry of Social Affairs and Health, the National Institute for Health and Welfare $\left(\mathrm{THL}^{21}\right)$ and Kela provides country specific information about the functioning of health care system in the country, needed vaccination and Finns' right to medical care abroad.

Consulates are the last actors who play a role in access to health care in case of emergencies (including a serious injury or illness). In these cases, consulates may give repayable loan that must be used for immediate and temporary treatment, as well as for returning to Finland. This loan is given in serious health problems regardless of the patient's possibilities at that moment to sign a reimbursement contract (Consulate service law 1999 13§3.). In non-emergency cases, Finnish consulates assist nationals by providing information and advice about local practices and available services. Beside consulates, Kela and the Nordic cooperation, there are also not-for-profit organizations and Finnish churches giving help in emergency situation in many countries like Spain, Greece, Thailand, Turkey and Cyprus. In Spain,

\footnotetext{
${ }^{19}$ Nordic Convention on Social Security (2014). https://www.finlex.fi/fi/laki/alkup/2014/20140289?search\%5Btype\%5D=pika\&search\%5Bpika\%5D=sosiaaliturvasopimus Accessed 15 March 2019.

${ }^{20}$ Foreign Ministry. https://um.fi/. Accessed 4 March 2019.

${ }^{21}$ THL. https://thl.fi. Accessed 11 March 2019.
} 
a group of Finnish volunteers called SOS Group, provides support services in the event of sudden illness, injury or other emergency. The SOS Group's website also provides up to date information on safety issues and living in Spain. ${ }^{22}$

\subsubsection{Pensions}

Finns moving abroad in their retirement years are allowed to have the pension they earned in Finland without any restrictions. Concerning pension payments abroad, Finland has a bank-based recognition system of citizens that requires beneficiaries to hold a Finnish bank account. ${ }^{23}$ In general, access to pensions for Finns residing in another EU Member State is regulated by the EU legislation. Finns residing outside the EU rely on social security cooperation between Nordic countries and agreements with third countries. The agreements with the US, Canada, Chile, and Israel includes old-age pensions and survivors' pensions, the agreement with Australia agreement covers old-age pensions only.

When it comes to the provision of information on how to access pensions earned in Finland, different actors are involved. First, Finnish consulates give advice and redirect citizens to the institutions where they can apply for pensions earned in Finland. Second, Kela's Center for International Affairs provides services for citizens who have questions about their social security and health rights abroad. In addition, the Finnish Centre for Pensions (ETK) gives advice on where to apply for pensions from abroad. Thirdly, Finland Society's senior citizens' advice service maintains a worldwide database of all the services provided for senior Finns abroad. Additionally, different non-state actors such as Finnish parishes abroad, the National Association of Finns in Sweden, Finland Society or Finnish Pensioners' Association are also involved in the delivery of information via websites, hotlines or physical meetings. In Sweden, the National Association of Finns in Sweden (Ruotsinsuomalaisten Keskusliitto, RSKL) also goes further than providing information. Namely, it lobbies for healthcare given by Finnish-speaking care providers for the elderly and builds a database of the elderly care institutions where care in Finnish language could be found.

\subsubsection{Family-Related Benefits}

Residence-based social security systems such as Finland's require a certain period of residence to qualify for benefits. If a Finn's stay abroad is temporary - less than 1 year - she/he is generally covered by the Finnish social security system, and is

\footnotetext{
${ }^{22}$ www.sosryhmat.net

${ }^{23}$ Työeläke. Claim your pension
} 
entitled to family benefits. This means that benefits already in payment can still be paid to her/him while she/he is abroad. A Finn can also apply for new benefits from Kela when living abroad if she/he has a Finnish bank account to ensure the electronic verification of identity.

Next to the specific situation of individuals who move abroad for short periods, Finns living abroad on a permanent basis (i.e. for more than 1 year) are not eligible for family benefits from Kela. The only exceptions to this rule concern family members of posted workers, civil servants, aid and missionary workers, students and researchers who accompany them abroad and live in the same household. These individuals have rights to family benefits even when their stay abroad lasts more than 1 year. Additionally, child benefits can be paid to children aged under 17 years old who stay abroad temporarily. However, if a recipient of partial care allowance of a child starts working in the foreign country, she/he is not anymore entitled to this family benefit, instead she/he moves under the social security legislation of employer's country.

Next to the EU legislation that regulates the right to child benefits for Finns residing in another Member State, some bilateral agreements with third countries also contain provisions in this area. The social security agreement with the United States covers for employees on a temporary assignment in the other country - health insurance, parental allowances and child benefits. ${ }^{24}$ The same type of agreement with Israel covers old-age pensions, survivors' pensions, child benefits and maternity grants.

Once more, the Nordic Convention on Social Security provides Finns residing in another Nordic country with a more favorable treatment than those living permanently outside the EU. A Finn and her/his partner and children are eligible for social insurance benefits in the Nordic country of residence or the Nordic country of work on equal terms with the citizens of that country. The family benefit system is quite similar all over the Nordic countries, but the level of benefits depends on the local living costs.

Compared to other states, the role of Finnish consulates in this area is limited by the fact that Finland does not produce birth certificate but instead every birth has to be registered into the Local Register Office (near the home municipality) where the person can order a life certificate when needed. Additionally, consulates abroad produce life certificates based on passport or other valid official identity document. For Finnish children born abroad (to at least one Finnish parent), the destination country's birth certificate of the child should be sent to the specific Finnish Local Register Office in Pietarsaari to ensure that they are registered as Finnish nationals. ${ }^{25}$

\footnotetext{
${ }^{24}$ Nordic Convention on Social Assistance and Social Services (1994). https://www.finlex.fi/fi/laki/ alkup/1993/19931481?search\%5Btype\%5D=pika\&search\%5Bpika\%5D=sosiaaliturvasopimus. Accessed 13 March 2019.

${ }^{25}$ Local Register Office. When must you notify your return to Finland? https://www.maistraatti.fi/ en/Services/instructions_on_relaying_information_about_expatriate_finns/When-must-younotify-your-return-to-Finland/. Accessed 8 March 2019.
} 


\subsubsection{Economic Hardship}

Finland's social assistance scheme is not exportable but, as noted earlier, Finns temporarily abroad who find themselves in a situation of economic hardship can apply for a repayable loan from consulates. Finnish consulates can help with: a) a grant to respond to immediate distress; b) a home-away allowance (against a repayment commitment if the deposit is not possible); c) borrowing money for travelling back home; or d) loaning money for the necessity and temporary care of a sickness if a Finn cannot obtain a deposit. Consulates may still help a Finn economically when she/he cannot give back a loan repayment due to the severity of her/his illness or other comparable cause (Act of Consular services 1999.).

\subsection{Conclusions}

In this chapter, we have shown that Finland does not have a widespread infrastructure nor a large amount of public policies or programmes that are specifically dedicated to its population abroad. In line with the presence of 1.6 million individuals of Finnish origin, the focus on Finland has traditionally been on religious, cultural and educational programmes over any other type of engagement with this population. In addition to the absence of diaspora specific public institutions, the Finnish consular network has very clearly defined missions which sets strong limits to the type of assistance Finnish citizens abroad can expect to receive. While this could lead to the conclusion that Finland is largely disinterested in its population permanently abroad, two specificities of the Finnish case still deserve to be highlighted. First, historically Seamans' Missions and more recently, Finnish Church have helped Finns aboard in need of help. Additionally, there is a strong network of Finnish non-profit organizations that take over some of the missions in the area of diaspora policies that most states usually give to public authorities. For instance, non-profit organizations run a consultative body that ensures the dialogue between the diaspora and Finnish authorities. Similarly, they also deliver a series of services in the area of social protection often thanks to project-based financial support of Finnish authorities. In that sense, it can be argued that Finland has a somewhat decentralized approach to diaspora engagement. Secondly, the focus on five social protection dimensions has highlighted that—while Finland has a residence-based welfare system-its commitment to cooperation with Nordic countries entails a large share of the diaspora concentrates de facto benefits from an access to destination country social protection systems that is more favourable than what is set by the EU framework. This commitment to Nordic cooperation allow to conclude that_-far from being disengaged-Finland's take on diaspora engagement is characterized by a strong commitment to regional integration. Summing up, the diaspora policy of the Finnish Government could be characterised as "reactive" to both the changing nature of Finnish mobility (i.e. increased tourism) and the concentration of its emigration in Nordic countries. 
Acknowledgements This chapter is part of the project "Migration and Transnational Social Protection in (Post)Crisis Europe (MiTSoPro)" that has received funding from the European Research Council (ERC) under the European Union's Horizon 2020 research and innovation programme (Grant agreement No. 680014). In addition to this chapter, readers can find a series of indicators comparing national social protection and diaspora policies across 40 countries on the following website: http://labos.ulg.ac.be/socialprotection/.

\section{References}

Castren, S. (2018). Seuraavissa eduskuntavaaleissa ulkosuomalainen voi äänestää kirjeitse. Suomen Silta, 1, 27. www.Choosehealthcare.fi.Hoitopaikanvalinta.fi.Accessed 4 Mar 2019.

Helin, S. (2017, May 17). Kahdesta miljoonasta ulkosuomalaisesta suuri osa on "kateissa" Ulkomailla asuvat ovat aina poikkeama tilastoissa. YLE National Boardcasting Company. https://yle.fi/uutiset/3-9613474. Accessed 7 Mar 2019.

Hyvärinen, M. (2017). Suomi-koulut ovat menestystarina. Suomen Silta, 2-3, 28-29.

Korkiasaari, J., \& Söderling, I. (2003). Finnish Emigration and Immigration after World War II Turku: Siirtolaisuusinstituutti. http://www.migrationinstitute.fi/files/pdf/artikkelit/finnish_ emigration_and_immigration_after_world_war_ii_0.pdf. Accessed 7 Mar 2019.

Lötjönen, K. (2013). Kelalle ropisee ilmoituksia tukien väärinkäytöstä - naapurit ja ex-kumppanit ilmiantajina. YLE National Board casting Company. https://yle.fi/uutiset/3-6863936. Accessed 9 Mar 2019.

Savolainen, L. (2015). Sosiaaliturvan alikäyttö tulee meille kalliimmaksi kuin väärinkäyttö "Moni tukeutuu mieluummin pikavippeihin". YLE National Board casting company. https:// yle.fi/uutiset/3-8447134. Accessed 11 Mar 2019.

Söderling, I. (2017). Suomalaisia muuttanut ulkomaille 1,4 miljoonaa - mutta mihin? Suomen Silta, 2-3, 16-17.

Strandberg, T. (2018). Suomen ulkomaankoulut ja Suomi-koulut ovat parasta koulutusvientiä Suomelle. Suomen Silta, 1, 26.

Uhari, M. (2016). Älä huijaa ankaraa Kelaa - Käräjille voi joutua, vaikka maksaisi tuet takaisin. Aamulehti. https://www.aamulehti.fi/kotimaa/ala-huijaa-ankaraa-kelaa-karajille-voi-joutuavaikka-maksaisi-tuet-takaisin-23778656. Accessed 11 Mar 2019. 
Open Access This chapter is licensed under the terms of the Creative Commons Attribution 4.0 International License (http://creativecommons.org/licenses/by/4.0/), which permits use, sharing, adaptation, distribution and reproduction in any medium or format, as long as you give appropriate credit to the original author(s) and the source, provide a link to the Creative Commons license and indicate if changes were made.

The images or other third party material in this chapter are included in the chapter's Creative Commons license, unless indicated otherwise in a credit line to the material. If material is not included in the chapter's Creative Commons license and your intended use is not permitted by statutory regulation or exceeds the permitted use, you will need to obtain permission directly from the copyright holder. 